\title{
Early-Life Iron Deficiency Anemia Programs the Hippocampal Epigenomic Landscape
}

\author{
Amanda K. Barks (D, Shirelle X. Liu (D), Michael K. Georgieff, Timothy C. Hallstrom and Phu V. Tran *(D) \\ Department of Pediatrics, University of Minnesota, Minneapolis, MN 55455, USA; barks012@umn.edu (A.K.B.); \\ liu00459@umn.edu (S.X.L.); georg001@umn.edu (M.K.G.); halls026@umn.edu (T.C.H.) \\ * Correspondence: tranx271@umn.edu; Tel.: +1-(612)-626-7964
}

check for updates

Citation: Barks, A.K.; Liu, S.X.; Georgieff, M.K.; Hallstrom, T.C.; Tran, P.V. Early-Life Iron Deficiency Anemia Programs the Hippocampal Epigenomic Landscape. Nutrients 2021, 13, 3857. https://doi.org/ $10.3390 /$ nu13113857

Academic Editor: Elad Tako

Received: 28 September 2021

Accepted: 25 October 2021

Published: 28 October 2021

Publisher's Note: MDPI stays neutral with regard to jurisdictional claims in published maps and institutional affiliations.

Copyright: (c) 2021 by the authors. Licensee MDPI, Basel, Switzerland. This article is an open access article distributed under the terms and conditions of the Creative Commons Attribution (CC BY) license (https:// creativecommons.org/licenses/by/ $4.0 /)$.

\begin{abstract}
Iron deficiency (ID) anemia is the foremost micronutrient deficiency worldwide, affecting around $40 \%$ of pregnant women and young children. ID during the prenatal and early postnatal periods has a pronounced effect on neurodevelopment, resulting in long-term effects such as cognitive impairment and increased risk for neuropsychiatric disorders. Treatment of ID has been complicated as it does not always resolve the long-lasting neurodevelopmental deficits. In animal models, developmental ID results in abnormal hippocampal structure and function associated with dysregulation of genes involved in neurotransmission and synaptic plasticity. Dysregulation of these genes is a likely proximate cause of the life-long deficits that follow developmental ID. However, a direct functional link between iron and gene dysregulation has yet to be elucidated. Iron-dependent epigenetic modifications are one mechanism by which ID could alter gene expression across the lifespan. The jumonji and AT-rich interaction domain-containing (JARID) protein and the Ten-Eleven Translocation (TET) proteins are two families of iron-dependent epigenetic modifiers that play critical roles during neural development by establishing proper gene regulation during critical periods of brain development. Therefore, JARIDs and TETs can contribute to the iron-mediated epigenetic mechanisms by which early-life ID directly causes stable changes in gene regulation across the life span.
\end{abstract}

Keywords: perinatal iron deficiency; neurodevelopment; epigenetics; JARIDs; TETs; cognition

\section{Introduction}

Increasing evidence indicates that early-life adverse events (e.g., malnutrition) can have a lasting impact on physiological and mental health [1,2]. One particularly wellstudied early-life adverse event is iron deficiency (ID), which affects $40-50 \%$ of pregnant women and preschool-aged children and is the most common micronutrient deficiency worldwide [3,4]. Given the prevalence of this early-life nutritional exposure, it is important to understand its effect on long-term health outcomes, and the biological basis underlying these effects. ID during the fetal and early childhood periods has a significant effect on neurodevelopment, resulting in cognitive, socio-emotional, and learning and memory deficits that last into early adulthood [5,6]. ID also carries long-term health risks, including increased risk for neuropsychiatric disorders such as autism and schizophrenia $[7,8]$. Parallel studies in pre-clinical models have shown that early-life ID results in abnormal hippocampal structure, function, and gene expression acutely during the period of rapid neurodevelopment and persistently into adulthood despite prompt iron therapy after diagnosis [9-18]. The persistent gene dysregulation likely drives the adult neurobehavioral abnormalities of developmental ID. However, specific iron-dependent mechanisms by which early-life ID alters gene expression across the lifespan are unknown. Thus, there is a need to understand the mechanisms by which early-life ID alters gene regulation in the developing brain and leads to permanent changes in the adult brain in order to design better therapeutic strategies to prevent and treat them.

Epigenetic modification is one mechanism by which environmental insults such as ID can enact permanent changes in gene expression [19-22]. Our group has previously 
demonstrated that one major epigenetic mechanism, histone methylation, is profoundly altered by ID via modulation of iron-containing and dependent jumonji and AT-rich interaction domain-containing (JARID) histone demethylases $[23,24]$. In addition, we have shown that early-life ID alters DNA methylation in the hippocampus, although the iron-dependent mechanism of these changes is unknown [25]. In this regard, the irondependent Ten-Eleven Translocation (TET) proteins [26-28], which oxidize methylcytosine to hydroxymethylcytosine and subsequent derivatives, could significantly contribute to the ID-induced DNA methylation changes. However, the effects of ID on the activity of TET proteins and their enzymatic products in the developing brain remain undetermined.

From a treatment standpoint, choline supplementation during late fetal or early postnatal life has been shown to mitigate behavioral abnormalities in models of genetic and early-life environmental insults, including ID [24,29-33]. Like supplements such as folic acid, betaine, vitamin B12, and L-methionine, choline is a methyl donor for Sadenosylmethionine (SAM), which is a substrate for DNA and histone methylation. Accordingly, maternal diets enriched with methyl-donors increase the methylation of DNA and histones in the epigenome of offspring [34-36]. In a rodent model of early-life ID, prenatal choline supplementation during the period of high iron demand in hippocampal development rescues recognition memory deficits and $B d n f$ dysregulation in formerly ID anemic rats by reversing underlying epigenetic dysregulation [24,29]. Thus, choline supplementation may be an effective treatment for developmental ID amenia by targeting the epigenetic mechanisms underlying the long-term sequelae of developmental ID anemia.

The persistence of neurocognitive deficits and gene dysregulation despite prompt treatment of ID with iron replacement indicates that better targeting of iron therapy and additional adjunct therapeutic options are needed. Until we have a better understanding of the cellular and molecular mechanisms underlying the lasting functional and gene expression changes associated with early-life ID, we cannot move forward with advancement of more effective prevention and treatment for this common developmental condition because iron repletion alone is not fully effective. The present review summarizes the state of knowledge and identifies gaps in our understanding of the iron-dependent molecular mechanisms underlying the long-term neurological effects of early-life ID.

\section{Main Text}

Iron deficiency during neural development causes long-term neurobehavioral outcomes.

ID is the foremost micronutrient deficiency worldwide, affecting an estimated $40-50 \%$ of pregnant women and preschool-aged children [3,37]. While prevalent in low- and middle-income countries, ID is also common in high-income countries, including the US, where up to $42 \%$ of pregnant women and $14 \%$ of $1-2$ year-olds experience ID [38-40]. With respect to health disparity, ID affects about $6 \%$ of women of child-bearing age in the US. However, among those women affected, Black and Hispanic are twice as likely to be affected compared to White or Asian women [41]. The prevalence of ID among these vulnerable populations is a major public health concern due to the well-documented effects of developmental ID on neurodevelopment.

Individuals who were iron-deficient during infancy exhibit long-lasting neurocognitive and neuropsychiatric abnormalities. Formerly iron-deficient (FID) children show evidence of neurocognitive impairments, including slower perceptual speed, poorer understanding of quantitative concepts, and impaired language abilities [42,43]. FID adolescents and young adults exhibit lower performance in reading and arithmetic tasks [44] as well as recognition memory and strategy shifting [6]. FID adults are prone to not complete secondary education or actively seek additional training [5]. In terms of neuropsychiatric outcomes, FID children exhibit lower positive affect, poorer performance on a delayed gratification task, and more passive or unengaged compared to iron-sufficient children [45-47]. Early adolescence FID individuals show an increased propensity for anxiety, depression, and aggression [44]. FID adults are more prone to report negative emotions and poor emotional health [5]. 
Low maternal iron intake and ID during pregnancy can increase the risk of autism spectrum disorder (ASD) [8] and schizophrenia spectrum disorder in offspring [7,48]. These associations are corroborated by a large-scale cohort study of more than 500,000 individuals where the prevalence of ASD, attention deficit and hyperactivity disorder (ADHD), and intellectual disability are increased in children of mothers diagnosed with anemia during the first 30-weeks of pregnancy [49]. It is noteworthy that the prevalence of these disorders did not increase when the diagnosis of anemia in mothers occurred after 30 weeks of pregnancy, suggesting that neurodevelopmental events during the first two trimesters of pregnancy are most critical for the atypical neuropsychiatric development and highly sensitive to iron insufficiency. Collectively, these clinical studies underscore a role for iron as a critical nutrient across neurodevelopment.

\subsection{Early-Life Iron Deficiency Modifies Gene Regulation and Epigenetic Landscape in the Adult Rat Hippocampus}

Understanding the biology behind the association of maternal and early postnatal ID with neurocognitive impairments and psychopathology risks is a prerequisite for developing effective prevention and treatment strategies. Based on a series of observational studies, two hypotheses are formulated to explicate the poor long-term neurodevelopmental outcomes. The structural defects hypothesis posits that developmental ID causes abnormalities ranging from gross structures (e.g., brain and white matter volumes) to fine ultrastructures (e.g., dendrite branching and synaptic spines) that persist despite later iron reconstitution $[13,15,50]$. The gene dysregulation hypothesis postulates that earlylife ID reprograms gene regulation, which in turn contributes to subsequent phenotypic changes [18,51-54]. These two hypotheses are not mutually exclusive, and their interactions likely drive abnormal structure during neurodevelopment and function throughout the lifetime, accounting for the risk of psychopathology in later life. The structural hypothesis is discussed elsewhere [55]. This review focuses on the gene dysregulation hypothesis and the potential underlying mechanisms.

\subsection{Early-Life Iron Deficiency Reprograms Gene Regulation}

Extensive gene dysregulation has been demonstrated in both rodent and porcine models of fetal-neonatal ID acutely during ID $[10,56]$ and persistently in adulthood following iron repletion $[18,54]$. The dysregulated genes implicate abnormal neurodevelopment and increased propensity of neuropsychiatric disorders $[10,18,54,56]$. These widespread and lasting effects implicate global and stable changes in gene regulatory mechanisms such as epigenetic regulation. Epigenetic regulation refers to covalent modifications of DNA and histones to alter gene transcriptional activity and phenotype without changes in the genetic code. Importantly, DNA and histone modifications can be altered depending on environmental exposures such as stress [57,58], toxicants [59-61], and nutrients [24,51-53,62,63]. Thus, epigenetic regulation can be a mechanism by which ID alters gene regulation during critical windows of the nervous system development, contributing to poor long-term neuropsychiatric outcomes.

\subsection{DNA Methylation and Hydroxymethylation}

DNA can be methylated by the covalent addition of a methyl group to cytosine nucleotides. Methylated DNA is generally associated with gene silencing, particularly when present at promoter regions, by inducing closed-state chromatin [64]. Both rat and porcine models of developmental ID demonstrate significant changes in DNA methylation at a genome-wide level; however, few of the differentially methylated CpG sites map to differentially expressed genes $[25,56]$. Thus, while clearly demonstrating altered patterns of DNA methylation, these studies do not address the functional significance of these changes.

Despite the evidence of altered global DNA methylation pattern, the biological mechanism by which fetal-neonatal ID directly mediates these changes remains unclear. A potential consideration is that methylated DNA (5-methylcytosine, $5 \mathrm{mC}$ ) can be oxidized by the iron-dependent family of TET methylcytosine dioxygenases, which absolutely require 
iron for their enzymatic activity (Figure 1A). If the iron-binding site is mutated, or if iron is depleted, TET proteins do not efficiently convert $5 \mathrm{mC}$ to 5 -hydroxymethylcytosine ( $5 \mathrm{hmC}$ ), resulting in significantly decreased global $5 \mathrm{hmC}$ levels [28]. Interestingly, TET expression increases in the central nervous system (CNS) during development, particularly as neurons mature. In the mouse hippocampus (Figure 1B), $5 \mathrm{hmC}$ levels increase significantly (2.6 fold) between postnatal day (P)7 and adulthood, predominantly within the exons of genes that become activated between these two timepoints [65]. Globally, 5hmC is enriched in the intragenic regions of genes that are highly transcribed [66]. Taken together, TET enzymes are highly active during brain development when they actively establish $5 \mathrm{hmC}$ levels as a stable epigenetic modification that plays a critical role in the regulation of neural-specific gene expression. In the context of fetal-neonatal ID, little is known about the roles of TETs. Therefore, additional studies are needed to determine the effect of a clinically relevant degree of ID on TET activity in the developing brain.

A

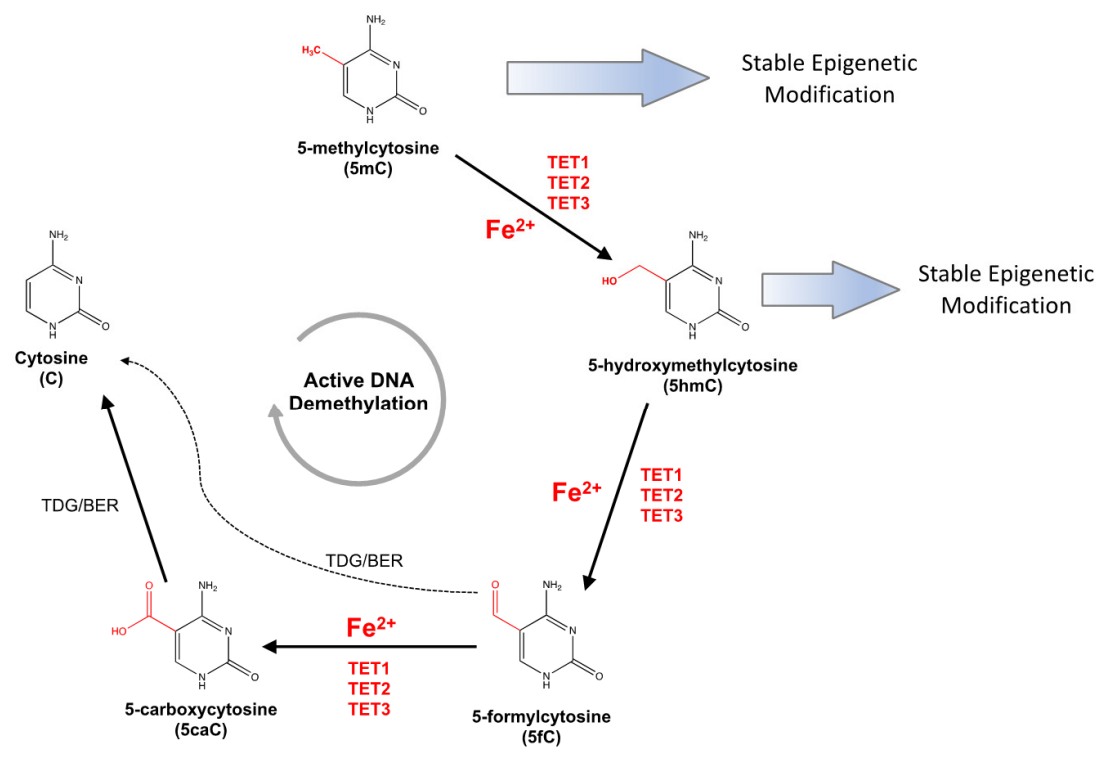

B

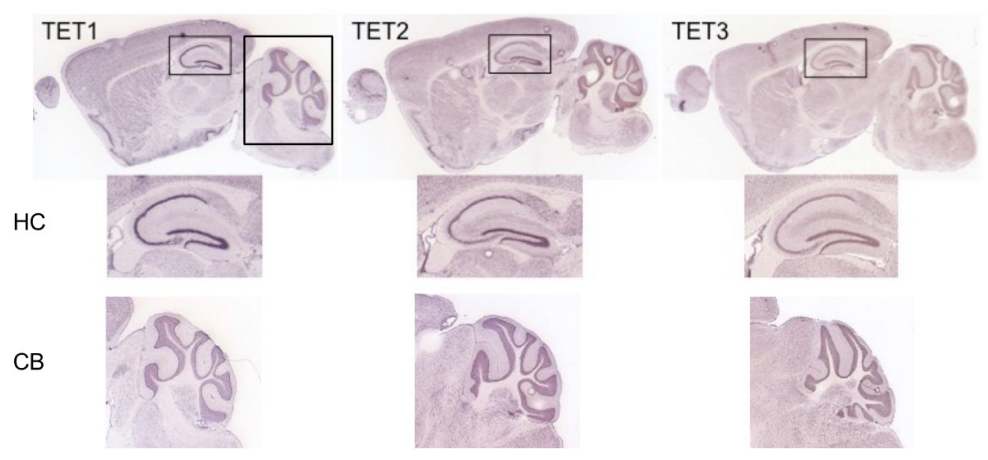

Figure 1. Iron-dependent Ten-Eleven Translocation (TET) proteins influence the epigenetic modifications of DNA methylation and hydroxymethylation. (A) Covalently modified cytosine bases are a major class of epigenetic modification. 5-methylcytosine $(5 \mathrm{mC})$ can be maintained long-term as a stable epigenetic modification or hydroxylated by the iron-dependent TET methylcytosine dioxygenases to 5-hydroxymethylcytosine $(5 \mathrm{hmC}) .5 \mathrm{hmC}$ can serve as a stable epigenetic modification or an intermediate in the active DNA demethylation pathway, which reverses modified cytosines to unmodified states by serial modifications mediated in by TETs and thymine DNA glycosylase (TDG). (B) Expression of TET dioxygenases in the adult mouse brain. All three TET are highly expressed in the mouse hippocampus (HC) and cerebellum (CB). Images modified from Allen Mouse Brain Atlas [67]. 


\subsection{Histone Methylation}

Histones can be acetylated, methylated, phosphorylated, and ubiquitinated. These modifications can alter gene transcriptional regulation by stably establishing activation or repression protein complexes. The histone code is complex and is understudied in the context of early-life ID. In the context of developmental ID, lysine demethylation of histones is particularly important because of its mechanistic dependence on iron (Figure 2A). Removal of methyl groups from lysine residues can be catalyzed by the JARID protein family, which absolutely requires iron for their catalytic activity [68,69]. It is noteworthy that the incorporation of iron into the Jumonji C (JmjC) domain is also critical for JARID's structural stability and function [68]. JARID protein family, which is also known as KDM (Lysine demethylase), has a strong preference for specific lysine targets, thereby producing differential transcriptional regulatory effects (Figure 2B). For instance, JARID1B (KDM5 family member) removes the methyl group from tri- and di-methylated histone $\mathrm{H} 3 \mathrm{ly}$ sine 4 (H3K4me3/2), leading to a less transcriptionally active chromatin conformation; whereas, JMJD3 (KDM6 family member) catalyzes tri- and di-methylated histone H3 lysine 27 (H3K27me3/2), resulting in a less repressed chromatin conformation [70,71]. Moreover, JARIDs regulate neuronal growth and differentiation during brain development [72-77]. Importantly, JARIDs can regulate $B d n f$ expression, which exhibits a long-term downregulation by early-life ID [17,75,78-81]. Fetal-neonatal ID produces a long-term downregulation of hippocampal JARIDs [23]. In addition, the adult formerly iron-deficient hippocampus exhibits lower expression of JMJD3 concomitant with a higher enrichment of H3K27me3 at the $B d n f$ promoter; these changes can account for the Bdnf downregulation [23,24]. Thus, the general downregulation of JARID subtypes in the iron-deficient and formerly iron-deficient hippocampi likely disrupts a complex balance between active and repressive chromatin structures, leading to permanent gene dysregulation beyond the critical period of brain development.

Collectively, early-life ID can alter histone methylations, contributing to the long-term gene expression changes in adulthood. Given the complexity of epigenetic regulation, additional studies are needed to fully assess the epigenetic modifications, particularly at gene promoters, in order to elucidate mechanisms contributing to the long-term gene dysregulation.

\subsection{Prenatal Choline Supplementation and Iron Deficiency Interact to Regulate the Rat Hippocampal Epigenomic Landscape}

Given the beneficial effects of prenatal choline supplementation in reversing the repression and epigenetic modifications of the hippocampal Bdnf gene by early-life ID [24], it is enticing to use choline as a prevention (prenatal period) or treatment (children diagnosed with ID anemia) in clinical studies [83]. However, there are several caveats to the use of such a potential epigenetic modulator in the treatment of ID. First, given multiple epigenetic modifications by ID, the therapeutic efficacy of modulating any single modification is unclear. Our recent genome-wide analysis reveals that prenatal choline supplementation produces a distinct epigenomic effect from early-life ID, where choline modifies specifically histone H3K9me3 landscape, particularly among loci regulating endocytosis, microgliosis, and neurogenesis in the adult rat hippocampus (Liu and Tran, unpublished observation). Second, the efficacy of epigenetic regulators has to be considered in the context of critical periods of neurodevelopment. For example, once the process of dendrite outgrowth is complete, altering gene expression by treatment with an epigenetic modulator cannot reverse the structural damage caused by ID since the critical period is closed. Therefore, appropriate timing of choline use in the context of neurodevelopment is crucial for its efficacy. Since the brain is not developmentally homogeneous, certain brain regions may be affected more or less than others depending on whether they are or are not in a rapid developmental period. Finally, potential adverse effects of inappropriate use of epigenetic modulators such as choline remain possible. While others have shown the beneficial effects of choline supplementation in normal rats in terms of cognitive function [84,85], we found little and even negative effects in our control iron-sufficient rats using a similar prenatal 
supplementation (gestational day 11 through 18) paradigm [18,29]. In addition, our recent genome-wide analysis of chromatin accessibility (ATAC) and histone H3K9me3 landscape shows that prenatal choline supplementation caused significant long-term changes in chromatin accessibility and H3K9me3 landscape in the adult rat hippocampus (Liu and Tran, unpublished observation). These observations indicate the need to continue to study appropriate choline dosing, timing, and duration of supplementation to avoid potential long-term adverse consequences.

A

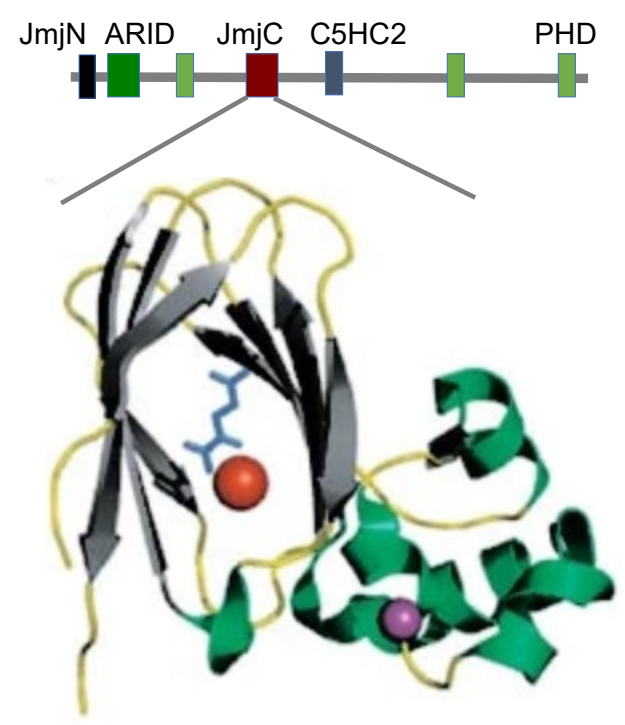

B

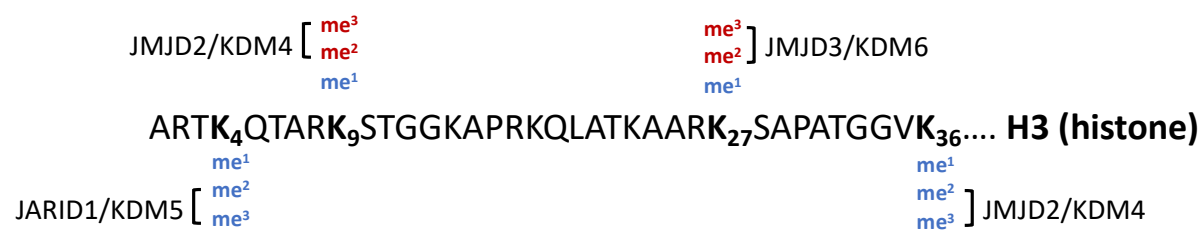

Figure 2. Iron-dependent jumonji and AT-rich interaction domain-containing (JARID) histone demethylase. (A) Illustration showing domains within JARID polypeptide. The Jumonji C (JmjC) domain is illustrated by 3D-modeling showing the iron (red) binding pocket with the co-factor alpha-ketoglutarate (blue). Image adapted from Klose, Kallin, and Zhang, Nature Reviews Genetics, 2006 [82]. (B) Major histone methylation sites within histone H3. Illustration depicting specific lysine (K) residues with histone demethylases (JARID/KDM). Enrichment of methylated K4 and K36 (blue) is associated with active transcription, whereas enrichment of methylated K9 and K27 (red) is associated with gene silencing (Adapted from Pedersen and Helin, 2010 [71]).

\section{Conclusions}

The emerging concept of the developmental origins of adult health and disease (DO$\mathrm{HaD}$ ) posits that the health outcomes in adulthood are determined in part by early-life exposures [86]. Fetal-neonatal ID represents a model of $\mathrm{DOHaD}$, where exposure to ID during development is associated with a lifetime risk of neural dysfunctions, including increased risk for intellectual disability, ASD, ADHD, and schizophrenia $[7,8,49]$. What mechanisms underlie the effects of fetal-neonatal ID on neurodevelopment to enact the DOHaD concept? While both structural deficits and gene expression reprogramming provide attractive hypotheses to account for lasting functional impairments, it is likely that both factors and their interactive effects contribute to the long-term health outcomes (Figure 3). Emerging evidence implicates the dysregulated iron-dependence epigenetic 
modifiers (JARIDs, TETs) as key regulators of the persistent epigenetic modifications even after the resolution of ID $[24,25,56]$, providing a causal and direct link between ID and gene dysregulation. In addition, ID-altered epigenome can also play an important role in the structural deficit hypothesis. In CNS development, neuronal migration, axonal growth, and synaptogenesis are regulated by the precisely timed gene expression during specific critical periods of development. These dynamic changes in gene expression are orchestrated in part by the precise changes to the epigenome across neurodevelopment $[65,66,87]$. If the iron-dependent JARIDs and TETs that orchestrate these developmental epigenetic changes are compromised by fetal-neonatal ID, then the dynamics of gene expression will be compromised as well, consequently leading to abnormal structural development.

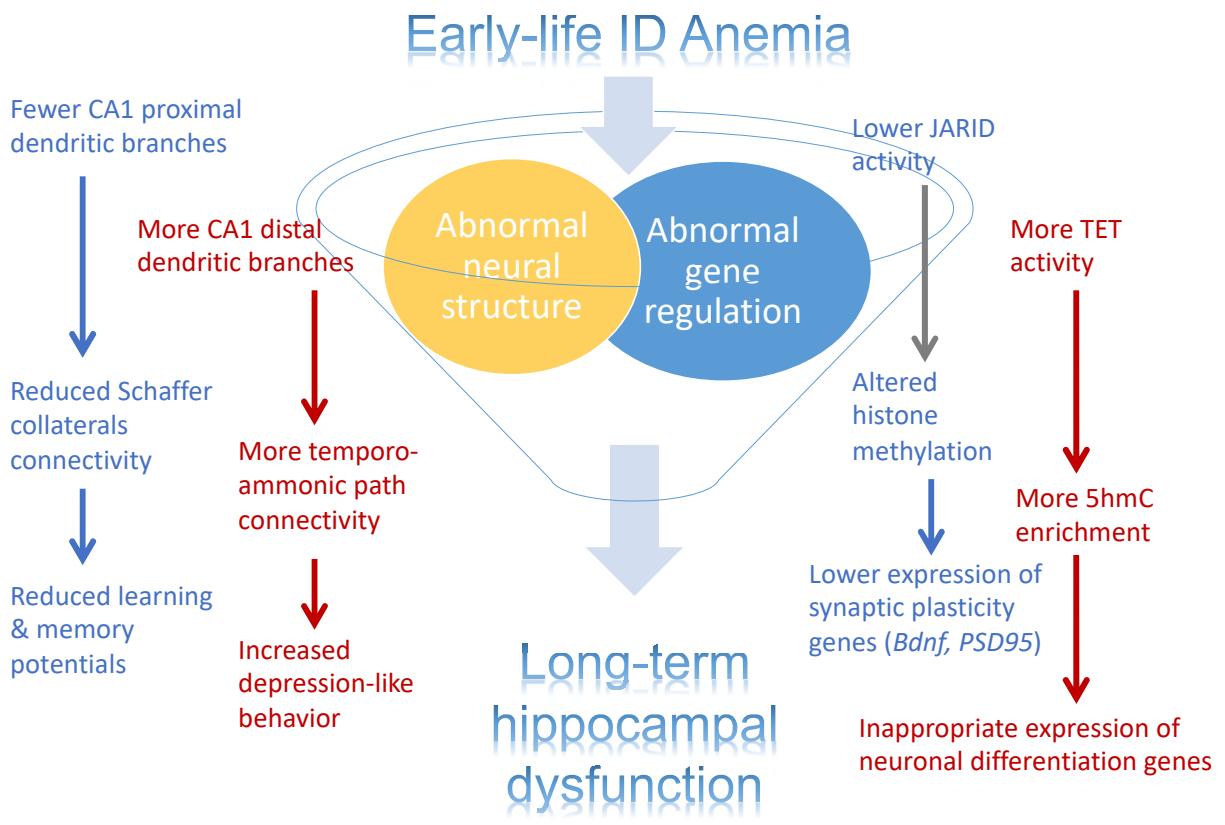

Figure 3. Effects of early-life iron deficiency (ID) anemia on the rat hippocampus. Illustration depicting the effects on early-life ID anemia on hippocampal structure and gene expression. Abnormal structure development, inappropriate gene expression, and their interaction are contributing factors to the abnormal hippocampal function in adult rats that were iron-deficient during fetal and neonatal life.

Given the global prevalence of fetal-neonatal ID, it is important to establish mechanisms underlying the long-term gene changes relevant to cognitive and emotional dysfunctions due to early-life ID to develop sound nutritional policy and practice that minimizes the risk of long-term neurobehavioral deficits. Prevention of ID during fetal and early postnatal life is an ideal and achievable goal with the provision of optimal nutritional health, including macro- (e.g., protein, fatty acids) and micronutrient (e.g., iron, zinc), to child-bearing age women as they enter pregnancy. Postnatally, the provision of human milk and maintenance of an optimal status of critical nutrients are key prevention strategies. As such, common gestational conditions such as maternal hypertension, diabetes, and obesity are major risk factors for early-life ID in a high-incomed society $[3,88,89]$. In particular, ID risk is double among Hispanic and Black child-bearing age women in the US, presenting a possible factor contributing to the multi-generational health disparity within these populations [41]. Thus, alternative treatment strategies may be successful. In this regard, dietary epigenetic modulators such as choline and folate are promising with a potentially beneficial therapeutic effect on neurodevelopment in the context of nutritional deficiency $[18,90]$; however, it is too soon to propose the use of these supplements as therapeutic interventions. Given the substantial changes in gene expression and the epigenome 
that can have a long-lasting adverse effect on fetal choline supplementation [18], more studies are needed to optimize the timing, dose, and duration of these agents.

Author Contributions: Conceptualization: A.K.B., M.K.G., T.C.H. and P.V.T.; writing-original draft preparation: A.K.B. and P.V.T.; writing-review and editing: A.K.B., S.X.L., M.K.G., T.C.H. and P.V.T.; project administration: P.V.T.; funding acquisition: A.K.B. and P.V.T. All authors have read and agreed to the published version of the manuscript.

Funding: This work was funded by the NIH, grant number F30HD093285 to A.K.B. and NIH R01NS099178 to P.V.T.

Institutional Review Board Statement: Not applicable.

Informed Consent Statement: Not applicable.

Data Availability Statement: Not applicable.

Conflicts of Interest: The authors declare no conflict of interest.

\section{References}

1. Chen, Y.; Baram, T.Z. Toward Understanding How Early-Life Stress Reprograms Cognitive and Emotional Brain Networks. Neuropsychopharmacology 2016, 41, 197-206. [CrossRef]

2. Vaiserman, A.M.; Koliada, A.K. Early-life adversity and long-term neurobehavioral outcomes: Epigenome as a bridge? Hum. Genom. 2017, 11. [CrossRef] [PubMed]

3. McLean, E.; Cogswell, M.; Egli, I.; Wojdyla, D.; De Benoist, B. Worldwide prevalence of anaemia, WHO Vitamin and Mineral Nutrition Information System, 1993-2005. Public Health Nutr. 2009, 12, 444-454. [CrossRef] [PubMed]

4. Stevens, G.A.; Finucane, M.M.; De-Regil, L.M.; Paciorek, C.J.; Flaxman, S.R.; Branca, F.; Peña-Rosas, J.P.; Bhutta, Z.A.; Ezzati, M. Global, regional, and national trends in haemoglobin concentration and prevalence of total and severe anaemia in children and pregnant and non-pregnant women for 1995-2011: A systematic analysis of population-representative data. Lancet Glob. Health 2013, 1, e16-e25. [CrossRef]

5. Lozoff, B.; Smith, J.B.; Kaciroti, N.; Clark, K.M.; Guevara, S.; Jimenez, E. Functional significance of early-life iron deficiency: Outcomes at 25 years. J. Pediatr. 2013, 163, 1260-1266. [CrossRef]

6. Lukowski, A.F.; Koss, M.; Burden, M.J.; Jonides, J.; Nelson, C.A.; Kaciroti, N.; Jimenez, E.; Lozoff, B. Iron deficiency in infancy and neurocognitive functioning at 19 years: Evidence of long-term deficits in executive function and recognition memory. Nutr. Neurosci. 2010, 13, 54-70. [CrossRef] [PubMed]

7. Insel, B.J.; Schaefer, C.A.; McKeague, I.W.; Susser, E.S.; Brown, A.S. Maternal iron deficiency and the risk of schizophrenia in offspring. Arch. Gen. Psychiatry 2008, 65, 1136-1144. [CrossRef] [PubMed]

8. Schmidt, R.J.; Tancredi, D.J.; Krakowiak, P.; Hansen, R.L.; Ozonoff, S. Maternal intake of supplemental iron and risk of autism spectrum disorder. Am. J. Epidemiol. 2014, 180, 890-900. [CrossRef]

9. Brunette, K.E.; Tran, P.V.; Wobken, J.D.; Carlson, E.S.; Georgieff, M.K. Gestational and Neonatal Iron Deficiency Alters Apical Dendrite Structure of CA1 Pyramidal Neurons in Adult Rat Hippocampus. Dev. Neurosci. 2010, 32, 238-248. [CrossRef] [PubMed]

10. Carlson, E.S.; Stead, J.D.H.; Neal, C.R.; Petryk, A.; Georgieff, M.K. Perinatal iron deficiency results in altered developmental expression of genes mediating energy metabolism and neuronal morphogenesis in hippocampus. Hippocampus 2007, 17, 679-691. [CrossRef]

11. Carlson, E.S.; Tkac, I.; Magid, R.; O'Connor, M.B.; Andrews, N.C.; Schallert, T.; Gunshin, H.; Georgieff, M.K.; Petryk, A. Iron Is Essential for Neuron Development and Memory Function in Mouse Hippocampus. J. Nutr. 2009, 139, 672-679. [CrossRef] [PubMed]

12. Fretham, S.J.B.; Carlson, E.S.; Georgieff, M.K. Neuronal-specific iron deficiency dysregulates mammalian target of rapamycin signaling during hippocampal development in nonanemic genetic mouse Models1,2. J. Nutr. 2013, 143, 260-266. [CrossRef] [PubMed]

13. Fretham, S.J.B.; Carlson, E.S.; Wobken, J.; Tran, P.V.; Petryk, A.; Georgieff, M.K. Temporal manipulation of transferrin-receptor-1dependent iron uptake identifies a sensitive period in mouse hippocampal neurodevelopment. Hippocampus 2012, 22, 1691-1702. [CrossRef] [PubMed]

14. Jorgenson, L.A.; Sun, M.; O'Connor, M.; Georgieff, M.K. Fetal iron deficiency disrupts the maturation of synaptic function and efficacy in area CA1 of the developing rat hippocampus. Hippocampus 2005, 15, 1094-1102. [CrossRef]

15. Jorgenson, L.A.; Wobken, J.D.; Georgieff, M.K. Perinatal Iron Deficiency Alters Apical Dendritic Growth in Hippocampal CA1 Pyramidal Neurons. Dev. Neurosci. 2003, 25, 412-420. [CrossRef]

16. Tran, P.V.; Carlson, E.S.; Fretham, S.J.B.; Georgieff, M.K. Early-Life Iron Deficiency Anemia Alters Neurotrophic Factor Expression and Hippocampal Neuron Differentiation in Male Rats. J. Nutr. 2008, 138, 2495. [CrossRef] [PubMed]

17. Tran, P.V.; Fretham, S.J.B.; Carlson, E.S.; Georgieff, M.K. Long-term reduction of hippocampal brain-derived neurotrophic factor activity after fetal-neonatal iron deficiency in adult rats. Pediatr. Res. 2009, 65, 493-498. [CrossRef] 
18. Tran, P.V.; Kennedy, B.C.; Pisansky, M.T.; Won, K.-J.; Gewirtz, J.C.; Simmons, R.A.; Georgieff, M.K. Prenatal Choline Supplementation Diminishes Early-Life Iron Deficiency-Induced Reprogramming of Molecular Networks Associated with Behavioral Abnormalities in the Adult Rat Hippocampus. J. Nutr. 2016, 146, 484-493. [CrossRef]

19. Dolinoy, D.C.; Jirtle, R.L. Environmental epigenomics in human health and disease. Environ. Mol. Mutagen. 2008, 49, 4-8. [CrossRef]

20. Feil, R. Environmental and nutritional effects on the epigenetic regulation of genes. Mutat. Res. Mol. Mech. Mutagen. 2006, 600, 46-57. [CrossRef] [PubMed]

21. Gomez-Verjan, J.C.; Barrera-Vázquez, O.S.; García-Velázquez, L.; Samper-Ternent, R.; Arroyo, P. Epigenetic variations due to nutritional status in early-life and its later impact on aging and disease. Clin. Genet. 2020, 98, 313-321. [CrossRef]

22. Stevens, A.J.; Rucklidge, J.J.; Kennedy, M.A. Epigenetics, nutrition and mental health. Is there a relationship? Nutr. Neurosci. 2018, 21, 602-613. [CrossRef]

23. Blegen, M.B.; Kennedy, B.C.; Thibert, K.A.; Gewirtz, J.C.; Tran, P.V.; Georgieff, M.K. Multigenerational effects of fetal-neonatal iron deficiency on hippocampal BDNF signaling. Physiol. Rep. 2013, 1, e00096. [CrossRef] [PubMed]

24. Tran, P.V.; Kennedy, B.C.; Lien, Y.-C.; Simmons, R.A.; Georgieff, M.K. Fetal iron deficiency induces chromatin remodeling at the Bdnf locus in adult rat hippocampus. Am. J. Physiol. Integr. Comp. Physiol. 2015, 308, R276-R282. [CrossRef] [PubMed]

25. Lien, Y.C.; Condon, D.E.; Georgieff, M.K.; Simmons, R.A.; Tran, P.V. Dysregulation of neuronal genes by fetal-neonatal iron deficiency anemia is associated with altered DNA methylation in the rat hippocampus. Nutrients 2019, 11, 1191. [CrossRef]

26. Hu, L.; Lu, J.; Cheng, J.; Rao, Q.; Li, Z.; Hou, H.; Lou, Z.; Zhang, L.; Li, W.; Gong, W.; et al. Structural insight into substrate preference for TET-mediated oxidation. Nature 2015, 527, 118-122. [CrossRef] [PubMed]

27. Kriaucionis, S.; Heintz, N. The Nuclear DNA Base 5-Hydroxymethylcytosine Is Present in Purkinje Neurons and the Brain. Science 2009, 324, 929-930. [CrossRef] [PubMed]

28. Tahiliani, M.; Koh, K.P.; Shen, Y.; Pastor, W.A.; Bandukwala, H.; Brudno, Y.; Agarwal, S.; Iyer, L.M.; Liu, D.R.; Aravind, L.; et al. Conversion of 5-Methylcytosine to 5-Hydroxymethylcytosine in Mammalian DNA by MLL Partner TET1. Science 2009, 324, 930-935. [CrossRef]

29. Kennedy, B.C.; Dimova, J.G.; Siddappa, A.J.M.; Tran, P.V.; Gewirtz, J.C.; Georgieff, M.K. Prenatal choline supplementation ameliorates the long-term neurobehavioral effects of fetal-neonatal iron deficiency in rats. J. Nutr. 2014, 144, 1858-1865. [CrossRef] [PubMed]

30. Nag, N.; Mellott, T.J.; Berger-Sweeney, J.E. Effects of postnatal dietary choline supplementation on motor regional brain volume and growth factor expression in a mouse model of Rett syndrome. Brain Res. 2008, 1237, 101-109. [CrossRef] [PubMed]

31. Schaevitz, L.; Berger-Sweeney, J.; Ricceri, L. One-carbon metabolism in neurodevelopmental disorders: Using broad-based nutraceutics to treat cognitive deficits in complex spectrum disorders. Neurosci. Biobehav. Rev. 2014, 46, 270-284. [CrossRef] [PubMed]

32. Thomas, J.D.; Abou, E.J.; Dominguez, H.D. Prenatal choline supplementation mitigates the adverse effects of prenatal alcohol exposure on development in rats. Neurotoxicol. Teratol. 2009, 31, 303-311. [CrossRef] [PubMed]

33. Thomas, J.D.; La Fiette, M.H.; Quinn, V.R.E.; Riley, E.P. Neonatal choline supplementation ameliorates the effects of prenatal alcohol exposure on a discrimination learning task in rats. Neurotoxicol. Teratol. 2000, 22, 703-711. [CrossRef]

34. Cooney, C.A.; Dave, A.A.; Wolff, G.L. Maternal methyl supplements in mice affect epigenetic variation and DNA methylation of offspring. J. Nutr. 2002, 132, 2393S-2400S. [CrossRef]

35. Davison, J.M.; Mellott, T.J.; Kovacheva, V.P.; Blusztajn, J.K. Gestational choline supply regulates methylation of histone H3, expression of histone methyltransferases G9a (Kmt1c) and Suv39h1 (Kmt1a), and DNA methylation of their genes in rat fetal liver and brain. J. Biol. Chem. 2009, 284, 1982-1989. [CrossRef]

36. Mehedint, M.G.; Niculescu, M.D.; Craciunescu, C.N.; Zeisel, S.H. Choline deficiency alters global histone methylation and epigenetic marking at the Rel site of the calbindin 1 gene. FASEB J. 2010, 24, 184-195. [CrossRef] [PubMed]

37. Yip, R. Iron Deficiency: Contemporary Scientific Issues and International Programmatic Approaches. J. Nutr. 1994, 124, 1479S1490S. [CrossRef]

38. Mei, Z.; Cogswell, M.E.; Looker, A.C.; Pfeiffer, C.M.; Cusick, S.E.; Lacher, D.A.; Grummer-Strawn, L.M. Assessment of iron status in US pregnant women from the National Health and Nutrition Examination Survey (NHANES), 1999-2006. Am. J. Clin. Nutr. 2011, 93, 1312-1320. [CrossRef]

39. Cogswell, M.E.; Looker, A.C.; Pfeiffer, C.M.; Cook, J.D.; Lacher, D.A.; Beard, J.L.; Lynch, S.R.; Grummer-Strawn, L.M. Assessment of iron deficiency in US preschool children and nonpregnant females of childbearing age: National Health and Nutrition Examination Survey 2003-2006. Am. J. Clin. Nutr. 2009, 89, 1334-1342. [CrossRef]

40. Auerbach, M.; Abernathy, J.; Juul, S.; Short, V.; Derman, R. Prevalence of iron deficiency in first trimester, nonanemic pregnant women. J. Matern. Fetal. Neonatal Med. 2021, 34, 1002-1005. [CrossRef] [PubMed]

41. Barton, J.C.; Wiener, H.H.; Acton, R.T.; Adams, P.C.; Eckfeldt, J.H.; Gordeuk, V.R.; Harris, E.L.; McLaren, C.E.; Harrison, H.; McLaren, G.D.; et al. Prevalence of iron deficiency in 62,685 women of seven race/ethnicity groups: The HEIRS Study. PLoS ONE 2020, 15, e0232125. [CrossRef]

42. Lozoff, B.; Jimenez, E.; Wolf, A.W. Long-Term Developmental Outcome of Infants with Iron Deficiency. N. Engl. J. Med 1991, 325, 687-694. [CrossRef] [PubMed] 
43. Tamura, T.; Goldenberg, R.L.; Hou, J.; Johnston, K.E.; Cliver, S.P.; Ramey, S.L.; Nelson, K.G. Cord serum ferritin concentrations and mental and psychomotor development of children at five years of age. J. Pediatr. 2002, 140, 165-170. [CrossRef]

44. Lozoff, B.; Jimenez, E.; Hagen, J.; Mollen, E.; Wolf, A.W. Poorer behavioral and developmental outcome more than 10 years after treatment for iron deficiency in infancy. Pediatrics 2000, 105, e51. [CrossRef] [PubMed]

45. Chang, S.; Wang, L.; Wang, Y.; Brouwer, I.D.; Kok, F.J.; Lozoff, B.; Chen, C. Iron-Deficiency Anemia in Infancy and Social Emotional Development in Preschool-Aged Chinese Children. Pediatrics 2011, 127, e927-e933. [CrossRef]

46. Lozoff, B. Iron deficiency and child development. Food Nutr. Bull. 2007, 28. [CrossRef] [PubMed]

47. Corapci, F.; Radan, A.E.; Lozoff, B. Iron deficiency in infancy and mother-child interaction at 5 years. J. Dev. Behav. Pediatr. 2006, 27, 371-378. [CrossRef]

48. Sørensen, H.J.; Nielsen, P.R.; Pedersen, C.B.; Mortensen, P.B. Association Between Prepartum Maternal Iron Deficiency and Offspring Risk of Schizophrenia: Population-Based Cohort Study With Linkage of Danish National Registers. Schizophr. Bull. 2011, 37, 982. [CrossRef] [PubMed]

49. Wiegersma, A.M.; Dalman, C.; Lee, B.K.; Karlsson, H.; Gardner, R.M. Association of Prenatal Maternal Anemia With Neurodevelopmental Disorders. JAMA Psychiatry 2019, 76, 1294. [CrossRef]

50. Hensch, T.K. Critical period regulation. Annu. Rev. Neurosci. 2004, 27, 549-579. [CrossRef]

51. Tyagi, E.; Zhuang, Y.; Agrawal, R.; Ying, Z.; Gomez-Pinilla, F. Interactive actions of Bdnf methylation and cell metabolism for building neural resilience under the influence of diet. Neurobiol. Dis. 2015, 73, 307-318. [CrossRef]

52. Zeisel, S. Choline, Other Methyl-Donors and Epigenetics. Nutrients 2017, 9, 445. [CrossRef] [PubMed]

53. Ly, A.; Ishiguro, L.; Kim, D.; Im, D.; Kim, S.E.; Sohn, K.J.; Croxford, R.; Kim, Y.I. Maternal folic acid supplementation modulates DNA methylation and gene expression in the rat offspring in a gestation period-dependent and organ-specific manner. J. Nutr. Biochem. 2016, 33, 103-110. [CrossRef] [PubMed]

54. Barks, A.; Fretham, S.J.B.; Georgieff, M.K.; Tran, P.V. Early-Life Neuronal-Specific Iron Deficiency Alters the Adult Mouse Hippocampal Transcriptome. J. Nutr. 2018, 148, 1521-1528. [CrossRef] [PubMed]

55. Barks, A.; Hall, A.M.; Tran, P.V.; Georgieff, M.K. Iron as a model nutrient for understanding the nutritional origins of neuropsychiatric disease. Pediatr. Res. 2019, 85, 176-182. [CrossRef]

56. Schachtschneider, K.M.; Liu, Y.; Rund, L.A.; Madsen, O.; Johnson, R.W.; Groenen, M.A.M.; Schook, L.B. Impact of neonatal iron deficiency on hippocampal DNA methylation and gene transcription in a porcine biomedical model of cognitive development. BMC Genomics 2016, 17, 1-14. [CrossRef] [PubMed]

57. Lubin, F.D.; Roth, T.L.; Sweatt, J.D. Epigenetic Regulation of bdnf Gene Transcription in the Consolidation of Fear Memory. J. Neurosci. 2008, 28, 10576-10586. [CrossRef]

58. McGowan, P.O.; Suderman, M.; Sasaki, A.; Huang, T.C.T.; Hallett, M.; Meaney, M.J.; Szyf, M. Broad Epigenetic Signature of Maternal Care in the Brain of Adult Rats. PLoS ONE 2011, 6, e14739. [CrossRef]

59. Anderson, O.S.; Nahar, M.S.; Faulk, C.; Jones, T.R.; Liao, C.; Kannan, K.; Weinhouse, C.; Rozek, L.S.; Dolinoy, D.C. Epigenetic responses following maternal dietary exposure to physiologically relevant levels of bisphenol A. Environ. Mol. Mutagen. 2012, 53, 334-342. [CrossRef]

60. McBirney, M.; King, S.E.; Pappalardo, M.; Houser, E.; Unkefer, M.; Nilsson, E.; Sadler-Riggleman, I.; Beck, D.; Winchester, P.; Skinner, M.K. Atrazine induced epigenetic transgenerational inheritance of disease, lean phenotype and sperm epimutation pathology biomarkers. PLoS ONE 2017, 12, e0184306. [CrossRef] [PubMed]

61. Perkins, A.; Lehmann, C.; Lawrence, R.C.; Kelly, S.J. Alcohol exposure during development: Impact on the epigenome. Int. J. Dev. Neurosci. 2013, 31, 391-397. [CrossRef] [PubMed]

62. Ke, X.; Xing, B.; Yu, B.; Yu, X.; Majnik, A.; Cohen, S.; Lane, R.; Joss-Moore, L. IUGR disrupts the PPAR $\gamma$-Setd8-H4K20me1 and Wnt signaling pathways in the juvenile rat hippocampus. Int. J. Dev. Neurosci. 2014, 38, 59-67. [CrossRef] [PubMed]

63. Waterland, R.A.; Jirtle, R.L. Transposable Elements: Targets for Early Nutritional Effects on Epigenetic Gene Regulation. Mol. Cell. Biol. 2003, 23, 5293-5300. [CrossRef] [PubMed]

64. Smith, Z.D.; Meissner, A. DNA methylation: Roles in mammalian development. Nat. Rev. Genet. 2013, 14, 204-220. [CrossRef]

65. Szulwach, K.E.; Li, X.; Li, Y.; Song, C.-X.; Wu, H.; Dai, Q.; Irier, H.; Upadhyay, A.K.; Gearing, M.; Levey, A.I.; et al. 5-hmCmediated epigenetic dynamics during postnatal neurodevelopment and aging. Nat. Neurosci. 2011, 14, 1607-1616. [CrossRef] [PubMed]

66. Lister, R.; Mukamel, E.A.; Nery, J.R.; Urich, M.; Puddifoot, C.A.; Johnson, N.D.; Lucero, J.; Huang, Y.; Dwork, A.J.; Schultz, M.D.; et al. Global Epigenomic Reconfiguration During Mammalian Brain Development. Science 2013, 341, 1237905. [CrossRef] [PubMed]

67. ISH Data: Allen Brain Atlas: Mouse Brain. Available online: https://mouse.brain-map.org/ (accessed on 27 October 2021).

68. Chen, Z.; Zang, J.; Whetstine, J.; Hong, X.; Davrazou, F.; Kutateladze, T.G.; Simpson, M.; Mao, Q.; Pan, C.-H.; Dai, S.; et al. Structural Insights into Histone Demethylation by JMJD2 Family Members. Cell 2006, 125, 691-702. [CrossRef] [PubMed]

69. Tsukada, Y.; Fang, J.; Erdjument-Bromage, H.; Warren, M.E.; Borchers, C.H.; Tempst, P.; Zhang, Y. Histone demethylation by a family of JmjC domain-containing proteins. Nature 2005, 439, 811-816. [CrossRef]

70. Kouzarides, T. Chromatin Modifications and Their Function. Cell 2007, 128, 693-705. [CrossRef] [PubMed]

71. Pedersen, M.T.; Helin, K. Histone demethylases in development and disease. Trends Cell Biol. 2010, 20, 662-671. [CrossRef] [PubMed] 
72. Albert, M.; Schmitz, S.U.; Kooistra, S.M.; Malatesta, M.; Morales Torres, C.; Rekling, J.C.; Johansen, J.V.; Abarrategui, I.; Helin, K. The Histone Demethylase Jarid1b Ensures Faithful Mouse Development by Protecting Developmental Genes from Aberrant H3K4me3. PLoS Genet. 2013, 9, e1003461. [CrossRef] [PubMed]

73. Fueyo, R.; García, M.A.; Martínez-Balbás, M.A. Jumonji family histone demethylases in neural development. Cell Tissue Res. 2014, 359, 87-98. [CrossRef] [PubMed]

74. Jepsen, K.; Solum, D.; Zhou, T.; McEvilly, R.J.; Kim, H.J.; Glass, C.K.; Hermanson, O.; Rosenfeld, M.G. SMRT-mediated repression of an H3K27 demethylase in progression from neural stem cell to neuron. Nature 2007, 450, 415-419. [CrossRef] [PubMed]

75. Liefke, R.; Oswald, F.; Alvarado, C.; Ferres-Marco, D.; Mittler, G.; Rodriguez, P.; Dominguez, M.; Borggrefe, T. Histone demethylase KDM5A is an integral part of the core Notch-RBP-J repressor complex. Genes Dev. 2010, 24, 590-601. [CrossRef] [PubMed]

76. Schmitz, S.U.; Albert, M.; Malatesta, M.; Morey, L.; Johansen, J.V.; Bak, M.; Tommerup, N.; Abarrategui, I.; Helin, K. Jarid1b targets genes regulating development and is involved in neural differentiation. EMBO J. 2011, 30, 4586-4600. [CrossRef]

77. Takahashi, M.; Kojima, M.; Nakajima, K.; Suzuki-Migishima, R.; Takeuchi, T. Functions of a jumonji-cyclin D1 pathway in the coordination of cell cycle exit and migration during neurogenesis in the mouse hindbrain. Dev. Biol. 2007, 303, 549-560. [CrossRef] [PubMed]

78. Cascante, A.; Klum, S.; Biswas, M.; Antolin-Fontes, B.; Barnabé-Heider, F.; Hermanson, O. Gene-specific methylation control of $\mathrm{H} 3 \mathrm{~K} 9$ and H3K36 on neurotrophic BDNF versus astroglial GFAP genes by KDM4A/C regulates neural stem cell differentiation. J. Mol. Biol. 2014, 426, 3467-3477. [CrossRef] [PubMed]

79. Klose, R.J.; Yan, Q.; Tothova, Z.; Yamane, K.; Erdjument-Bromage, H.; Tempst, P.; Gilliland, D.G.; Zhang, Y.; Kaelin, W.G. The Retinoblastoma Binding Protein RBP2 Is an H3K4 Demethylase. Cell 2007, 128, 889-900. [CrossRef] [PubMed]

80. Li, G.; Margueron, R.; Ku, M.; Chambon, P.; Bernstein, B.E.; Reinberg, D. Jarid2 and PRC2, partners in regulating gene expression. Genes Dev. 2010, 24, 368-380. [CrossRef] [PubMed]

81. Pasini, D.; Cloos, P.A.C.; Walfridsson, J.; Olsson, L.; Bukowski, J.P.; Johansen, J.V.; Bak, M.; Tommerup, N.; Rappsilber, J.; Helin, K. JARID2 regulates binding of the Polycomb repressive complex 2 to target genes in ES cells. Nature 2010, 464, 306-310. [CrossRef] [PubMed]

82. Klose, R.J.; Kallin, E.M.; Zhang, Y. JmjC-domain-containing proteins and histone demethylation. Nat. Rev. Genet. 2006, 7, 715-727. [CrossRef] [PubMed]

83. Georgieff, M.K.; Ramel, S.E.; Cusick, S.E. Nutritional influences on brain development. Acta Paediatr. 2018, 107, 1310-1321. [CrossRef] [PubMed]

84. Zeisel, S.H. Nutritional Importance of Choline for Brain Development. J. Am. Coll. Nutr. 2004, 23, 621S-626S. [CrossRef] [PubMed]

85. Zeisel, S.H.; Da Costa, K.A. Choline: An essential nutrient for public health. Nutr. Rev. 2009, 67, 615-623. [CrossRef] [PubMed]

86. Heindel, J.J.; Vandenberg, L.N. Developmental origins of health and disease: A paradigm for understanding disease cause and prevention. Curr. Opin. Pediatr. 2015, 27, 248-253. [CrossRef] [PubMed]

87. Hahn, M.A.; Qiu, R.; Wu, X.; Li, A.X.; Zhang, H.; Wang, J.; Jui, J.; Jin, S.G.; Jiang, Y.; Pfeifer, G.P.; et al. Dynamics of 5Hydroxymethylcytosine and Chromatin Marks in Mammalian Neurogenesis. Cell Rep. 2013, 3, 291-300. [CrossRef]

88. Kling, P.J. 50 Years Ago in The Journal of Pediatrics: Iron Metabolism in Premature Infants: II. Prevention of Iron Deficiency. J. Pediatr. 2014, 164, 768. [CrossRef]

89. Siddappa, A.M.; Rao, R.; Long, J.D.; Widness, J.A.; Georgieff, M.K. The Assessment of Newborn Iron Stores at Birth: A Review of the Literature and Standards for Ferritin Concentrations. Neonatology 2007, 92, 73-82. [CrossRef]

90. Kennedy, B.C.; Tran, P.V.; Kohli, M.; Maertens, J.J.; Gewirtz, J.C.; Georgieff, M.K. Beneficial effects of postnatal choline supplementation on long-Term neurocognitive deficit resulting from fetal-Neonatal iron deficiency. Behav. Brain Res. 2018, 336, 40-43. [CrossRef] [PubMed] 